\title{
Celebrity Endorsement and Brand Credibility in the Carbonated Soft Drink Industry in Sri Lanka
}

\author{
Vadivelu Thusyanthy ${ }^{1}$ \\ ${ }^{1}$ Department of Economics and Management, Vavuniya Campus of the University of Jaffna, Vavuniya, Sri \\ Lanka \\ Correspondence: Vadivelu Thusyanthy, Department of Economics and Management, Vavuniya Campus of the \\ University of Jaffna, Pambaimaddu, Vavuniya, Sri Lanka. E-mail: thusi86@vau.jfn.ac.lk
}

Received: November 18, 2017

Accepted: May 21, 2018

Online Published: June 15, 2018

doi:10.5539/ijbm.v13n7p93

URL: https://doi.org/10.5539/ijbm.v13n7p93

\begin{abstract}
This study aims to assess the degree of celebrity endorsement and brand credibility in the carbonated soft drink industry in Sri Lanka. Questionnaires were used to collect the data from youth educated consumers of Sri Lankan Universities. Unidimensionality, reliability and validity assessments were performed to confirm scale reliability and validity, whereas one sample t-test was conducted to test hypotheses using 338 responses. The results revealed that the degree of celebrity endorsement and brand credibility were at low levels in the carbonated soft drink industry in Sri Lanka, especially among youth educated consumers. The findings of this empirical study can be effectively utilized by marketing managers in the carbonated soft drink industry in Sri Lanka, in their effort to develop and implement successful and strong celebrity endorsement and brand credibility related strategies.
\end{abstract}

Keywords: celebrity endorsement, brand credibility, carbonated soft drink industry, Sri Lanka, youth

\section{Introduction}

The food and beverage industry performs a vital role in expanding economic opportunity and it is the fastest growing sector across the world as well as Sri Lanka (Gehlhar \& Regmi, 2005; Peiris, 2014; Vlachvei \& Oustapassidis, 1998) since food and beverages are common to human life and health. Indeed, soft drinks sector is one of the fastest growing, most innovative and rapidly changing areas in the food and beverage industry (Gehlhar \& Regmi, 2005; Leatherhead Food Research, 2014; United Nations Industrial Development Organization, 2014). Bloomberg (2011) implies that the carbonated soft drink market is the largest segment in the global soft drink market, whereas Bruce (2011) argues that carbonated soft drink industry is one of the significant and growing industries in Sri Lanka, especially among the educated youth generation. Notably, Coca Cola and Pepsi Cola have strong global brand value in the global carbonated soft drink industry (Smithers Pira, 2014), while Elephant House, Coca Cola and Pepsi Cola have higher brand value in the carbonated soft drink industry in Sri Lanka (Mendis, 2012). Therefore, this study considers the carbonated soft drink industry, which includes three key players and brands namely, Elephant House, Coca Cola and Pepsi Cola. Nevertheless, many companies including the companies who are in the carbonated soft drink industry use celebrity endorsement as one of the effective advertising strategies to get competitive advantage (Kamins, Brand, Hoeke, \& Moe, 1989; Spry, Pappu, \& Cornwell, 2011). One-in-four advertisements use celebrity endorsement (MarketWatch, 2006; Pughazhendi \& Ravindran, 2012), since it is a more effective tool in advertising (Muda, Musa \& Putit, 2012). In fact, Friedman and Friedman (1979) indicate that celebrities are more effective than other types of endorsers, such as 'the professional expert', 'the company manager', or 'the typical consumer'. To illustrate this effectiveness of celebrity endorsement, Seno and Lukas (2007) cite Thomaselli and Neff (2004), '[i]n 2004, Gillette signed an endorsement deal with soccer celebrity David Beckham worth between \$US 30 and \$US 50 million'. For this effectiveness of celebrity endorsement, companies who are in the soft drink and carbonated soft drink industry spend huge amounts on celebrities to endorse their product (VinayagaMoorthy \& Madevan, 2014), but what is the degree of youth educated consumers' perceived evaluation on celebrity endorsement in the carbonated soft drink industry in Sri Lanka? Extant published research does not answer this question.

According to Spry et al. (2011) celebrity endorsement perhaps associate with a higher level of brand credibility. In fact, firms can keep their promises via the brand, which is known as brand credibility (Erdem \& Swait, 2004). 
This brand credibility is significant to the carbonated soft drink industry (Alam, Arshad \& Shabbir, 2012), but what is the degree of youth educated consumers' perceived evaluation on brand credibility in the carbonated soft drink industry in Sri Lanka? Extant published research does not answer this question. Further, these preceding two questions convey the two gaps in the relevant literatures. Thus, this study attempt to answer these two questions and fill these gaps by empirically and comprehensively examining the degree of celebrity endorsement and brand credibility in the carbonated soft drink industry among the educated youth generation in Sri Lanka, since this industry is one of the significant industries in Sri Lanka (Bruce, 2011).

The rest of this study is organized as follows: the next section literature review, followed by method, data analysis and results, and discussion. The final section offers the limitations and further research directions.

\section{Literature Review}

\subsection{Celebrity Endorsement}

Nowadays most of the marketers use celebrity endorsement as an effective promotional tool. McCracken (1989) defines celebrity endorsement as 'any individual who enjoys public recognition and who uses this recognition on behalf of a consumer good by appearing with it in an advertisement'.

Analysis of scientific literature reveals that the concept of celebrity endorsement rest on two general models: the source credibility model and source attractiveness model (e.g., Erdogan, 1999; Johansson \& Sparredal, 2002; Ohanian, 1990, 1991). Source credibility model includes two sub dimensions that are expertise and trustworthiness (De Los Salmones, Dominguez \& Herrero, 2013; Dholakia \& Stemthal, 1977; Goldsmith, Lafferty \& Newell, 2000; Hovland, Irving \& Harold, 1953; Kelman \& Hovland, 1953; Ohanian, 1991; Ratneshwar \& Chaiken, 1991; Solomon, 1996). Nevertheless, the source attractiveness model includes four sub dimensions are endorser's familiarity, likability, similarity and attractiveness to the respondent (e.g., McCracken, 1989; McGuire, 1985; Ohanian, 1990). Further, both source credibility model and the attractiveness are used by Ohanian (1990) to define three sub dimensions (attractiveness, expertise and trustworthiness) of celebrity endorsement.

The three sub dimensions of Ohanian (1990) are used by many recent studies (e.g., Hussain, Mehmood \& Khan, 2012; Lord \& Putrevu, 2009; Muda, Musa, Mohamed \& Borhan, 2014; Spry et al., 2011; Wei \& Lu, 2013) to measure the construct of celebrity endorsement and this study also considers attractiveness, expertise and trustworthiness are the sub dimensions of celebrity endorsement as replication to the existing literature (see Figure 1). Furthermore, operational definitions for the dimensions of celebrity endorsement (i.e., attractiveness, expertise and trustworthiness) are given in Table 1.

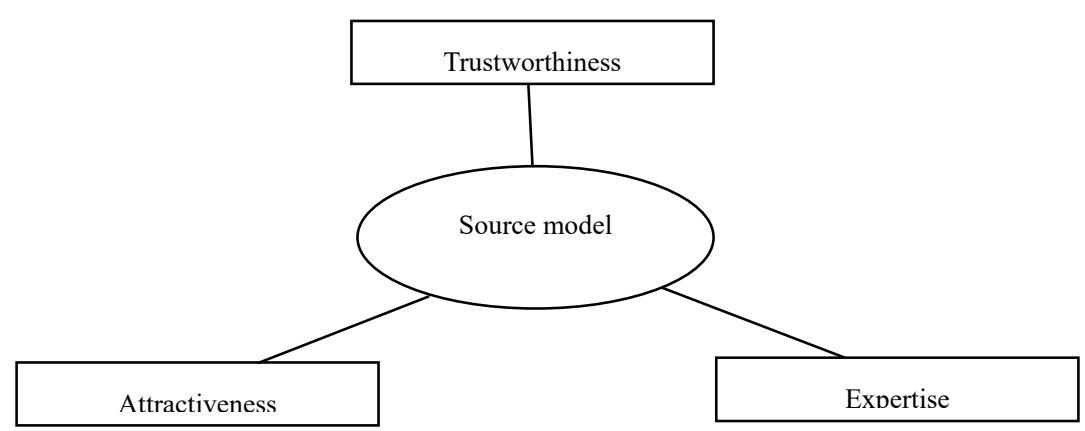

Figure 1. Ohanian source model for celebrity endorsement and dimensions

Table 1. Definition for celebrity endorsement dimensions

\begin{tabular}{llll}
\hline Construct & Dimensions & Definitions for this study & Definition adopt \\
\hline $\begin{array}{l}\text { Celebrity } \\
\text { endorsement }\end{array}$ & Attractiveness & $\begin{array}{l}\text { It is the endorser's personal attribute that would very } \\
\text { much manipulate the effectiveness of the endorsement. }\end{array}$ & $\begin{array}{l}\text { Silvera and Austad } \\
\text { (2004) }\end{array}$ \\
& Expertise & $\begin{array}{l}\text { It is the extent to which a communicator is perceived to } \\
\text { be a source of valid affirmations. }\end{array}$ & Hovland et al. (1953) \\
& Trustworthiness & $\begin{array}{l}\text { It is an endorser's honesty, integrity and believability } \\
\text { and it depends on the perceptions of target audience. }\end{array}$ & Erdogan (1999) \\
& &
\end{tabular}


Since, celebrity endorsement in advertisements is important to the carbonated soft drink industry (VinayagaMoorthy \& Madevan, 2014), there is a need to assess the degree of celebrity endorsement in this industry. Notably, the companies who are in the carbonated soft drink industry spend around 35 per cent of the total cost for advertising and they allocate millions of dollars for celebrity endorsement in advertisements and therefore, celebrity endorsement is high degree in the carbonated soft drink industry (e.g., Ojha, 2013; Singh, 2012; VinayagaMoorthy \& Madevan, 2014). Further, even though there has been no recent statistics available to show the amount spent on celebrity endorsement in the Sri Lankan carbonated soft drink industry, and generally the celebrity endorsement is high degree in the carbonated soft drink industry in Asian countries such as in South Korea (e.g., Money, Shimp \& Sakano, 2006) and India (e.g., Goutam, 2013) and thus, the researcher assumed that the celebrity endorsement is high degree in the carbonated soft drink industry in Sri Lanka, especially among the educated youth generation. According to the above argument the first hypothesis is advanced.

H1: The degree of youth educated consumers 'perceived evaluation on celebrity endorsement is at a high level in the carbonated soft drink industry in Sri Lanka.

Indeed, firms make a huge investment on celebrity endorsement, which is an effective advertising strategy (Elberse \& Verleun, 2012). These investments for celebrity endorsement perhaps associate with a higher level of brand credibility (Spry et al., 2011).

\subsection{Brand Credibility}

Credibility is one of the significant attributes of a brand (Maathuis, Rodenburg \& Sikkel, 2004; Spry et al., 2011). Erdem and Swait (2004) define brand credibility is the believability of a brand, which has the willingness (i.e., trustworthiness) and ability (i.e., expertise) to deliver what has been promised.

Analysis of past scientific literature in consumer marketing, global marketing, marketing and logistics, and retailing and consumer services has found that the topic of brand credibility rest on Erdem and Swait (2004) brand credibility model (e.g., Alam et al., 2012; Kemp \& Bui, 2011; Sweeney \& Swai, 2008; Wang \& Yang, 2010). Indeed landmark study of Hovland et al. (1953) is adapted to the brand context by Erdem and Swait (2004) and they develops brand credibility model. Accordingly, brand credibility comprises two key dimensions: trustworthiness and expertise (Erdem \& Swait, 2004).

The two dimensions of brand credibility (Erdem \& Swait, 2004) are used by many recent brand credibility related studies (e.g., Alam et al., 2012; Kemp \& Bui, 2011; Spry et al., 2011; Sweeney \& Swait, 2008; Wang \& Yang, 2010) to measure the construct of brand credibility. Thus, this study also considers trustworthiness and expertise as dimensions of brand credibility as replication to existing literature (see Figure 2). In addition, operational definitions for trustworthiness and expertise are given in Table 2.

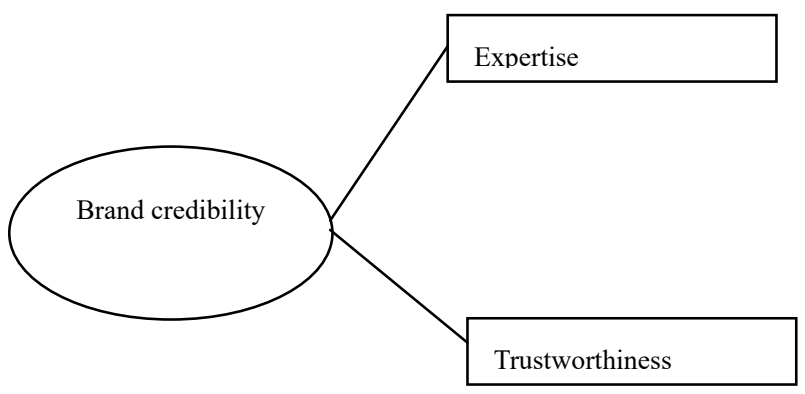

Figure 2. Erdem and swait brand credibility model

Table 2. Definition for brand credibility dimensions

\begin{tabular}{llll}
\hline Construct & Dimensions & Definitions for this study & Definition adopt \\
\hline $\begin{array}{l}\text { Brand } \\
\text { credibility }\end{array}$ & Trustworthiness & Trustworthiness implies that a brand is willing to deliver & Erdem and Swait (2004) \\
& what is promised. & Erdem and Swait (2004) \\
& Expertise & $\begin{array}{l}\text { Expertise means that capable or ability to continuously } \\
\text { deliver what has been promised. }\end{array}$ & \\
\hline
\end{tabular}

Brand credibility performs an important role in the beverage industry, especially it is vital for and high degree in 
the carbonated soft drink industry (e.g., Alam et al., 2012). Though there has been no recent statistics available to show the degree of brand credibility in the Sri Lankan carbonated soft drink industry, and generally the brand credibility is high degree in the carbonated soft drink industry in Asian countries such as in Pakistan (e.g., Alam et al., 2012) and thus, the researcher assumed that the brand credibility is high degree in the carbonated soft drink industry in Sri Lanka, especially among the educated youth generation. According to the above argument the second hypothesis is advanced.

$\mathrm{H} 2$ : The degree of youth educated consumers' perceived evaluation on brand credibility is at a high level in the carbonated soft drink industry in Sri Lanka.

\section{Method}

\subsection{Sample}

Previous carbonated soft drink related studies considered educated youth generation as target population including, especially university undergraduate students (Atilgan, Aksoy \& Akinci, 2005; Koordeman, Anschutz, Van Baaren \& Engels, 2010; Mathew, Casamassimo \& Hayes, 2002; Netemeyer et al., 2004). Therefore, this study too considered educated youth generation studying in Sri Lankan universities (undergraduate students) as target population. Clearly, the population was defined as 'educated youth generation between the age of 18 and 26 who had been studying in Sri Lankan universities (i.e., undergraduate students), and who has consumed carbonated soft drinks'. The final sample was selected using a judgmental sampling method, where number of sample was 381 undergraduates from Sri Lankan universities.

\subsection{Measures and Measurement}

Measurement scales adapted from previous studies are summarized in Table 3. Celebrity endorsement was measured using fifteen item scale devised by Ohanian (1990), which measures celebrity endorsement dimensions of attractiveness, expertise and trustworthiness. Further, expertise and trustworthiness were considered sub-dimensions of brand credibility, and six items were used for measuring brand credibility (Erdem \& Swait, 2004).

Table 3. Measurement scales

\begin{tabular}{|c|c|c|}
\hline Code & \multicolumn{2}{|l|}{ Celebrity endorsement } \\
\hline & (i) Attractiveness & Ohanian \\
\hline CE01 & The appeared celebrity in the product category advertisement is attractive & $(1990)$ \\
\hline CE02 & The appeared celebrity in the product category advertisement is classy (fashionable) & \\
\hline CE03 & The appeared celebrity in the product category advertisement is beautiful & \\
\hline CE04 & The appeared celebrity in the product category advertisement is elegant & \\
\hline \multirow[t]{2}{*}{ CE05 } & The appeared celebrity in the product category advertisement is sexy & \\
\hline & (ii) Expertise & Ohanian \\
\hline CE06 & The appeared celebrity in the advertisement is an expert to represent the product category & $(1990)$ \\
\hline CE07 & $\begin{array}{l}\text { The appeared celebrity in the advertisement is an experienced person to represent in the product } \\
\text { category }\end{array}$ & \\
\hline CE08 & $\begin{array}{l}\text { The appeared celebrity in the product category advertisement is knowledgeable to represent the product } \\
\text { category }\end{array}$ & \\
\hline CE09 & $\begin{array}{l}\text { The appeared celebrity in the product category advertisement is qualified to represent the product } \\
\text { category }\end{array}$ & \\
\hline \multirow[t]{2}{*}{ CE10 } & $\begin{array}{l}\text { The appeared celebrity in the product category advertisement is a skilled person to represent the product } \\
\text { category }\end{array}$ & \\
\hline & (iii) Trustworthiness & Ohanian \\
\hline CE11 & The appeared celebrity in the advertisement is a dependable person in the product category & $(1990)$ \\
\hline CE12 & $\begin{array}{l}\text { The appeared celebrity in the product category advertisement is honest person to represent the product } \\
\text { category }\end{array}$ & \\
\hline CE13 & $\begin{array}{l}\text { The appeared celebrity in the product category advertisement is a reliable person to represent the } \\
\text { product category }\end{array}$ & \\
\hline CE14 & $\begin{array}{l}\text { The appeared celebrity in the product category advertisement is a sincere person to represent the product } \\
\text { category }\end{array}$ & \\
\hline CE15 & The appeared celebrity in the product category advertisement is a trustworthy person to represent the & \\
\hline
\end{tabular}




\begin{tabular}{|c|c|c|}
\hline & \multicolumn{2}{|l|}{ product category } \\
\hline & \multicolumn{2}{|l|}{ Brand credibility } \\
\hline & (i) Trustworthiness & Erdem and \\
\hline $\mathrm{BC} 01$ & Particular brand in the product category delivers what it promises & Swait (2004) \\
\hline $\mathrm{BC} 02$ & Particular brand's product category are believable & \\
\hline $\mathrm{BC} 03$ & Particular brand in the product category name can trust & \\
\hline \multirow[t]{2}{*}{ BC04 } & Particular brand in the product category never pretend anything that it doesn't have & \\
\hline & (ii) Expertise & Erdem and \\
\hline $\mathrm{BC} 05$ & $\begin{array}{l}\text { Particular brand in the product category reminds of someone who's competent and knows what is } \\
\text { doing }\end{array}$ & Swait (2004) \\
\hline $\mathrm{BC} 06$ & Particular brand in the product category has the ability to deliver what it promises & \\
\hline
\end{tabular}

As can be seen in Table 3, the measurement scales for the constructs (21 items) were used to develop a questionnaire in English. This questionnaire is divided into three sections (i.e., Section A-C). The section A was developed to measure celebrity endorsement, followed by section B, which was developed to measure brand credibility. Finally, section $\mathrm{C}$ was developed to measure demographics, including, gender, age and parental income. All items were measured on a five-point Likert scale ranging from ' $1=$ Strongly Disagree' to ' 5 = Strongly Agree'.

\subsection{Pre-Test}

First, the developed 21 items questionnaire was pre-tested in a pilot study by six marketing academics and six marketing managers. Based on these twelve experts' comments, the wording and layout of the questions were rearranged. Second, the modified questionnaire was subject to pre-test in a pilot study with a sample of 38 undergraduate students from universities in Sri Lanka. Based on the pilot study with undergraduates reworded several questions to enhance the clarity. Then, the main study followed with 21 items.

\subsection{Data Collection}

Questionnaires were distributed to 381 samples of undergraduate students and 338 usable samples were obtained after excluding the incomplete ones, yielding an 89 per cent response rate.

\subsection{Statistical Treatment of Data}

This study used both descriptive statistics (i.e., mean and standard deviation) and inferential statistics (i.e., one sample t-test at .05 significance level, by using SPSS 19 software to test the hypotheses namely, H1 and H2), where these are the major two types of statistics (Owen, 2009). Further, the mean scores of the 5-point Likert scale measurement (mean scores for low, moderate and high levels) were adopted from Hair, Black, Babin, Anderson and Tatham (2006) to determine the degree of celebrity endorsement and brand creditability (e.g., Thusyanthy \& Senthilnathan, 2013; Thusyanthy \& Tharanikaran, 2015; Thusyanthy, 2016). These mean scores as decision criteria were used in the one sample t-test statistical analysis in order to test the hypotheses namely, H1 and H2 (see Table 4).

Table 4. Decision criteria

\begin{tabular}{ll}
\hline Mean value & Decision \\
\hline Between 1 and 2.49 & Low level \\
Between 2.5 and 3.49 & Moderate level \\
Between 3.5 and 5 & High level \\
\hline
\end{tabular}

\section{Data Analysis and Results}

\subsection{Sample Profile}

The sample $(\mathrm{n}=338)$ was composed by 56.8 percent of male and 43.2 percent of female. With respect to age group, high portion of the respondents was aged between 24 and 26 years (41.72 percent), whereas 27.81 percent and 30.47 percent of respondents age intervals $18-20$ and $20-23$, respectively. Regarding the parents income level, 13.61 percent of the respondent's parents had monthly income below 30000; 23.96 percent, 30000-99000; 43.79 percent, 100000-169000; and 18.64 percent, above 170000 . 


\subsection{Unidimensionality Assessment}

Unidimensionality refers that all items forming an instrument are measuring the same thing in common (Briggs \& Cheek, 1986; Cortina, 1993; Hattie, 1985; Lumsden, 1961). Unidimensionality can be established via principal component factor analysis with Varimax rotation to allow for inter-correlations among the dimensions (Brown et al., 1997; Chung \& Pennebaker, 2008; Johnson, 2005; Zaichkowsky, 1985). Thus, 338 samples in this study were also subject to factor analysis by using principle component analysis with Varimax rotation procedure in order to explore the unidimensionality of each scale by applying SPSS 19 software.

As a preliminary to conduct a factor analysis, the sampling adequacy and the appropriateness of the factor analysis were established through Kaiser-Meyer-Olkin (KMO) test (celebrity endorsement $=0.876$; brand credibility $=0.770$ ) and Bartlett's test of Sphericity (celebrity endorsement $=\chi 2=1938.11, \mathrm{p}<0.000, \mathrm{df}=105$; brand credibility $=\chi 2=511.72, \mathrm{p}<0.000, \mathrm{df}=15$ ), respectively.

After determining the sampling adequacy and appropriateness of the factor analysis, every single item for each dimension of celebrity endorsement and brand credibility was individually submitted for a factor analysis by using principle component analysis with Varimax rotation (see Table 5 and Table 6).

Table 4. Principal component analysis results for celebrity endorsement

\begin{tabular}{lccc}
\hline Celebrity endorsement items & \multicolumn{3}{c}{ Components } \\
\cline { 2 - 4 } & Component 1 & Component 2 & Component 3 \\
\hline Attractiveness 1 & 0.140 & 0.039 & $\mathbf{0 . 7 4 9}$ \\
Attractiveness 2 & 0.142 & -0.035 & $\mathbf{0 . 8 3 0}$ \\
Attractiveness 3 & 0.198 & 0.051 & $\mathbf{0 . 7 2 7}$ \\
Attractiveness 4 & 0.205 & 0.081 & $\mathbf{0 . 6 9 8}$ \\
Attractiveness 5 & -0.068 & 0.114 & 0.249 \\
Expertise 1 & $\mathbf{0 . 6 9 8}$ & 0.073 \\
Expertise 2 & $\mathbf{0 . 7 7 7}$ & 0.093 & 0.079 \\
Expertise 3 & $\mathbf{0 . 7 5 7}$ & 0.117 \\
Expertise 4 & $\mathbf{0 . 7 4 8}$ & 0.195 \\
Expertise 5 & $\mathbf{0 . 6 3 9}$ & 0.252 & 0.213 \\
Trustworthiness 1 & 0.281 & 0.289 & -0.022 \\
Trustworthiness 2 & 0.296 & 0.279 & -0.002 \\
Trustworthiness 3 & 0.279 & 0.367 & 0.097 \\
Trustworthiness 4 & 0.077 & $\mathbf{0 . 6 1 0}$ & 0.017 \\
Trustworthiness 5 & 0.210 & $\mathbf{0 . 7 3 9}$ & 1.128 \\
Eigenvalues & 5.234 & $\mathbf{0 . 7 7 0}$ & 7.519 \\
Variance explained (per cent) & 34.891 & $\mathbf{0 . 6 6 0}$ & 58.278 \\
Accumulated variance (per cent) & 34.819 & $\mathbf{0 . 7 4 0}$ & 2.380 \\
\hline
\end{tabular}

Notes. Factor loadings after Varimax rotation of three components extracted by principal components extraction by using SPSS 19 software; factor loadings of far above 0.40 are presented in bold-face type.

Table 5. Principal component analysis results for brand credibility

\begin{tabular}{lcc}
\hline Brand credibility & \multicolumn{2}{c}{ Components } \\
\cline { 2 - 3 } items & Component 1 & Component 2 \\
\hline Trustworthiness 1 & $\mathbf{0 . 7 4 8}$ & 0.178 \\
Trustworthiness 2 & $\mathbf{0 . 7 7 8}$ & 0.095 \\
Trustworthiness 3 & $\mathbf{0 . 7 9 1}$ & 0.132 \\
Trustworthiness 4 & $\mathbf{0 . 6 0 5}$ & 0.337 \\
Expertise 1 & 0.060 & $\mathbf{0 . 9 1 5}$ \\
Expertise 2 & 0.343 & $\mathbf{0 . 7 7 2}$ \\
Eigenvalues & 2.841 & 1.042 \\
Variance explained (per cent) & 47.348 & 17.359 \\
Accumulated variance (per cent) & 47.348 & 64.707 \\
\hline
\end{tabular}

Notes. Factor loadings after Varimax rotation of two components extracted by principal components extraction by using SPSS 19 software; factor loadings of far above 0.40 are presented in bold-face type. 
The factors/components 1, 2 and 3 in Table 5 were interpreted as expertise, trustworthiness and attractiveness, respectively, whilst factors/components 1 and 2 in Table 6 were defined as trustworthiness and expertise, respectively.

It is notable that factors needed eigenvalue greater than one, and number of factors extracted should account for as a minimum 50 per cent or 60 per cent of the total variance interpreted (Hair, Anderson, Tatham, \& Black, 1998; Kaiser, 1960; Streiner, 1994; Ledesma \& Valero-Mora, 2007). As consistent with these criteria, the results of factor analysis revealed that a three factor with 15 items (Table 5) and a two factor with 6 items (Table 6) representing the eigenvalues greater than one, and a three factor accounted for 58.278 per cent of the accumulated variance, while a two factor explained 64.707 per cent of the total variance. Accordingly, as suggested in eigenvalue rule by Kaiser (1960), the three factors in Table 5 and the two factors in Table 6 were selected.

As can be seen in Table 5 and Table 6, all factor loadings were significant at the 0.05 level and factor loadings of far above 0.40 were presented in bold-face type. Indeed, all individual item factor loadings for their respective components were far above the required value of 0.40 (Bagozzi \& Baumgartner, 1994; Clark \& Watson, 1995) and thus, there was no necessity for eliminating any items. In fact, these results ultimately lead to an acceptance of the unidimensionality of two constructs, which were used in this study.

\subsection{Reliability and Validity}

Beckstead (2013) suggested that Cronbach's alpha coefficient is most commonly used index of reliability. Cronbach's alpha for each dimension ranged from 0.698 to 0.844 . Since, these reliability estimates exceeded the recommended standard of 0.70 (Nunnally, 1978; Thusyanthy \& Senthilnathan, 2012 cite George \& Mallery, 2003) and thus, satisfactory reliability for the dimensions achieved (see Table 7).

Most of the previous studies used construct validity to test the goodness of measures (Larkina, Mesagnoa, Berry, \& Spittle, 2014; Rossiter, 2011; Lee, 2013). In addition, construct validity is assessed through convergent and discriminant validity. As consistent with the past studies, this study used construct reliability and average variance extracted to assess the convergent validity (Tharanikaran, Sritharan \& Thusyanthy 2017 cite Choi, Huang, Jeffrey \& Baek, 2013 and Wei \& Lu, 2013). Accordingly, the construct reliability for all dimensions, exceed the benchmark of 0.70 (Fornell \& Larcker, 1981), whilst average variance extracted exceed the threshold value of 0.50 (Hair et al., 1998) indicated that they had acceptable levels of convergent validity (see Table 7).

Table 6. Reliability and convergent validity assessment results

\begin{tabular}{lccc}
\hline Items & Cronbach's alpha & \multicolumn{2}{c}{ Convergent validity } \\
\cline { 3 - 4 } & & CR & 0.52 \\
\hline Attractiveness & 0.788 & 0.81 & 0.53 \\
Expertise & 0.844 & 0.84 & 0.51 \\
Trustworthiness & 0.801 & 0.85 & 0.54 \\
Trustworthiness & 0.752 & 0.83 & 0.72 \\
Expertise & 0.698 & 0.84 & $>0.50($ Hair et al., 1998)
\end{tabular}

Notes. CR, construct reliability; AVE, average variance extracted; Cronbatch's alpha calculation by using SPSS 19 software.

Discriminant validity was assessed using the procedure has been suggested by Fornell and Larcker (1981). Fornell and Larcker (1981) suggest that the average variance extracted for a construct should be substantially higher than the squared correlation of two constructs. The results for constructs and dimensions indicated that sufficient discriminant validity because the average variance extracted for each dimension was greater than the squared correlations between dimensions (see Table 8). 
Table 7. Discriminant validity assessment results

\begin{tabular}{|c|c|c|c|c|c|c|}
\hline \multirow{2}{*}{\multicolumn{2}{|c|}{$\begin{array}{l}\text { Construct/ } \\
\text { Dimensions }\end{array}$}} & \multicolumn{3}{|c|}{ Celebrity endorsement } & \multicolumn{2}{|c|}{ Brand credibility } \\
\hline & & $\mathrm{A}$ & $\mathrm{E}$ & $\mathrm{T}$ & TR & EX \\
\hline \multirow{3}{*}{ CE } & $\mathbf{A}$ & 0.52 & $0.59 * *$ & $0.19^{* *}$ & & \\
\hline & $\mathbf{E}$ & 0.12 & 0.53 & $0.35 * *$ & & \\
\hline & $\mathbf{T}$ & 0.04 & 0.35 & 0.51 & & \\
\hline \multirow{2}{*}{ BC } & TR & & & & 0.54 & $0.47 * *$ \\
\hline & EX & & & & 0.22 & 0.72 \\
\hline
\end{tabular}

Notes. CE, celebrity endorsement; BC, brand credibility; A, attractiveness; E, expertise; T, trustworthiness; TR, trustworthiness; EX, Expertise; values on the diagonal in bold indicate the average variance extracted for the dimensions; the scores in the upper diagonal are Pearson correlations and $* * p<0.05$; the scores in the lower diagonal are the squares of the correlations; discriminant validity calculation gathered from SPSS 19 software.

\subsection{Descriptive Statistic Analysis and Results}

Using SPSS 19 software, descriptive statistics has been calculated. In fact, the means for celebrity endorsement and brand credibility were 2.18 and 2.33, respectively on a five-point Likert scale and thus, indicating lower level of means (Hair et al., 2006). Further, corresponding standard deviations for celebrity endorsement and brand credibility were 0.63 and 0.61 , respectively, which reflected the acceptable variability within the data set.

\subsection{Inferential Statistic Analysis: Hypothesis Testing and Results}

To test $\mathrm{H} 1$ and H2, this study used one sample t-test (see Table 9). The decision criteria in Table 4 were adopted to determine the degree of youth educated consumers' perceived evaluation on celebrity endorsement and brand credibility in the carbonated soft drink industry in Sri Lanka.

Table 8. One sample T-test result

\begin{tabular}{|c|c|c|c|c|c|c|c|}
\hline \multirow[t]{2}{*}{ Variable } & \multicolumn{2}{|c|}{ Assumed mean } & \multirow[t]{2}{*}{ Observed mean } & \multicolumn{2}{|c|}{$\mathrm{t}$-value } & \multicolumn{2}{|c|}{ Sig.level } \\
\hline & LB & UB & & LB & UB & LB & UB \\
\hline Celebrity endorsement & 1 & 2.5 & 2.18 & 34.42 & -9.20 & 0.000 & 0.000 \\
\hline Brand credibility & 1 & 2.5 & 2.33 & 39.62 & -4.92 & 0.000 & 0.000 \\
\hline
\end{tabular}

Notes. LB, lower boundary; UB, upper boundary; one sample t-test calculation gathered from SPSS 19 software.

As indicated in the Table 9, significance values of 0.000 for both lower and upper boundaries (i.e., $p<0.05$ ) in celebrity endorsement and brand credibility shows that there are significance differences between assumed means and observed means. Clearly, the observed means 2.18 and 2.33 for celebrity endorsement and brand credibility, respectively have fallen the low level range of $1-2.5$, which has represented the lower and upper boundaries of assumed mean. It is thus, the degree of youth educated consumers' perceived evaluation on celebrity endorsement and brand credibility are in low level in the carbonated industry in Sri Lanka. Notably, the one sample- t-test failed to offer support for $\mathrm{H} 1$ and $\mathrm{H} 2$.

\section{Discussion}

\subsection{Theoretical Implications}

$\mathrm{H} 1$ predicted that the degree of youth educated consumers' perceived evaluation on celebrity endorsement is at a high level in the carbonated soft drink industry in Sri Lanka; however, there was no support for this high level, and not consistent with previous studies. In particular, celebrity endorsement is high degree in the carbonated soft drink industry in Asian countries such as in South Korea and India (e.g., Goutam, 2013; Money et al., 2006). Therefore, the researcher assumed that the celebrity endorsement is high degree in the carbonated soft drink industry in Sri Lanka, especially among the educated youth generation. However, the H1 not supported. There is a possible explanation for this result. This study considered educated youth generation as target population, since they have more rational knowledge than typical consumers (Martin, 2005), which may lead to have less credible for the celebrity endorsement, and thus the results suggested that low level. The celebrity endorsement might have had high level, if the target population whole Sri Lankan consumers. Nevertheless, this study offers the empirical support to close the first gap. Consequently, the answer gets for the first research question is that celebrity endorsement at a low level in the carbonated soft drink industry in Sri Lanka, especially among the educated youth generation. 
The results indicate that the degree of youth educated consumers' perceived evaluation on brand credibility is at a low level in the carbonated soft drink industry in Sri Lanka, and not provided support for $\mathrm{H} 2$, and not consistent with past study. In fact, Alam et al. (2012) argue that brand credibility is at high degree in the carbonated soft drink industry, especially in Pakistan. Accordingly, the researcher assumed that the brand credibility is high degree in the carbonated soft drink industry in Sri Lanka, especially among the educated youth generation. However, the H2 not supported. Nevertheless, the possible explanation for this result is that this study selected educated youth generation as target population. The brand credibility might have had high level, if the target population was the whole Sri Lankan consumers. Moreover, this empirical study assists to close the second gap. Consequently, the answer gets for the second research question is that brand credibility at a low level in the carbonated soft drink industry in Sri Lanka, especially among the educated youth generation.

\subsection{Managerial Implications}

Marketing managers in the carbonated soft drink industry in Sri Lanka can effectively use the finding in this empirical study to develop and implement successful celebrity endorsement and brand credibility related strategies. Present study indicates that the degree of youth educated consumers' perceived evaluation of celebrity endorsement and brand credibility are in the low level in the carbonated soft drink industry in Sri Lanka. In fact, the celebrity endorsement is an effective advertising tool in the carbonated soft drink industry (VinayagaMoorthy \& Madevan, 2014), and brand credibility performs a vital role in this same industry (Alam et al., 2012), however the degree of both celebrity endorsement and brand credibility in the carbonated soft drink industry are in low level among the educated youth generation in Sri Lanka. Therefore, the marketing managers in this industry should concentrate these findings and try to use more credible celebrity endorsers in advertisements based on their attractiveness, expertise and trustworthiness, and try to build strong brand credibility to get the sustainable competitive advantage among the educated youth generation in Sri Lanka.

\subsection{Limitations and Future Research Directions}

The limitation of this study was mainly related to the generalization of findings due to the usage of student sample, since this sample has unique characteristics and non-representativeness of the population and thus, threatens the external validity (Zdravkovic, Magnusson \& Stanley, 2010). However, many past studies used this same sample and therefore, this study also used student sample as replication to the existing literature (Junco \& Cotton, 2012; Yoo \& Donthu, 2001; Yoshida \& Gordon, 2012). In addition, the data for this study was cross-sectional in nature. However, longitudinal data could be revealed an interesting result.

There are several avenues for future research. Previous studies have shown that celebrity endorsement impact on many variables such as, customer based brand equity, brand attitude, customers' brand perception and purchase intention, brand loyalty and word of mouth, consumer risk perception, brand image, advertising effectiveness, brand recall and brand recognition (Biswas, Biswas \& Das, 2006; Bush, Martin \& Bush, 2004; Hakimi, Abedniya \& Zaeim, 2011; Kamins, 1989; Jain, 2011; Sharma \& Kumar, 2013; Spry et al., 2011). Therefore, in future research, the impact of celebrity endorsement and its dimensions, namely attractiveness, expertise and trustworthiness on the abovementioned variables could be examined in the carbonated soft drink industry. Further, Kemp and Bui (2011) imply that brand credibility partially mediates the relationship between health motivation and self-brand connection; Alam et al. (2012) affirm that brand credibility mediates the association between trustworthiness, perceived quality and customer loyalty; Shamim and Butt (2013) assert that brand credibility mediates and strengthen the relationship between consumer based brand equity and brand attitude; and Hur, Kim and Woo (2014) clime that corporate brand credibility mediates the association between corporate social responsibility and corporate reputation. Therefore, the brand credibility could be considered as mediating variable with the preceding variables in the same carbonated soft drink industry, and it is another avenue for possible further research.

\section{References}

Alam, A., Arshad, M. U., \& Sayyed, S. A. (2012). Brand credibility, customer loyalty and the role of religious orientation. Journal of Marketing and Logistics, 24(4), 583-598. https://doi.org/10.1108/13555851211259034

Atilgan, E., Safak, A., \& Serekan, A. (2005). Determinants of the brand equity: A verification approach in the beverage industry in Turkey. Marketing Intelligence and Planning, 23(3), 237-248. https://doi.org/10.1108/02634500510597283

Bagozzi, R. P., \& Baumgartner, H. (1994). The evaluation of structural equation models and hypothesis testing. In R.P., Bagozzi (Eds.), Principles of marketing research (pp. 386-422). Cambridge: Blackwell Publishers. 
Beckstead, J. W. (2013). On measurements and their quality: Paper 1: Reliability-history, issues and procedures. International Journal of Nursing Studies, 50(7), 968-973. https://doi.org/10.1016/j.ijnurstu.2013.04.005

Biswas, D., Biswas, A., \& Das, N. (2006). The differential effects of celebrity and expert endorsements on consumer risk perceptions. Journal of Advertising, 35(2), 17-31. http://www.jstor.org/stable/20460723

Bloomberg. (2011). Research and markets: In 2014, the global soft drink market is. Retrieved 05 July 2016 , from http://www.bloomberg.com/apps/news?pid=conewsstory\&tkr=KO:AR\&sid=aZ4BSchtab9I

Briggs, S. R., \& Cheek, J. M. (1986). The role of factor analysis in the development and evaluation of $\begin{array}{lllll}\text { personality scales. } & \text { Journal }\end{array}$ https://doi.org/10.1111/j.1467-6494.1986.tb00391.x

Brown, T. A., Chorpita, B. F., Korotitsch, W., \& Barlow, D. H. (1997). Psychometric properties of the depression anxiety stress scales (DASS) in clinical samples. Behaviour Research and Therapy, 35(1), 79-89. https://doi.org/10.1348/014466506X158996

Bruce, B. (2011). Could Kik Cola do well against Coke and Pepsi in Sri Lanka? Retrieved 05 July 2016, from http://www.foodbev.com/news/can-kik-cola-kick-coke-and-pepsi-in-sri-lanka\#.VFuMHfmUd5A

Bush, A. J., Martin, C. A., \& Bush, V. D. (2004). Sports celebrity influence on the behavioral intentions of generation Y. Journal of Advertising Research, 44(1), 108-119. https://doi.org/10.1017/S0021849904040206

Chung, C. K., \& Pennebaker, J. W. (2008). Revealing dimensions of thinking in open-ended self-descriptions: An automated meaning extraction method for natural language. Journal of Research in Personality, 42(1), 96-132. https://doi.org/10.1016/j.jrp.2007.04.006

Clark, L. A., \& Watson, D. (1995). Constructing validity: Basic issues in objective scale development. Psychological Assessment, 7(3), 309-319. http://dx.doi.org/10.1037/1040-3590.7.3.309

Cortina, J. M. (1993). What is coefficient alpha? An examination of theory and applications. Journal of Applied Psychology, 78(1), 98-104. http://dx.doi.org/10.1037//0021-9010.78.1.98

De Los Salmones, M., Dominguez, R., \& Herrero, A. (2013). Communication using celebrities in the non-profit sector: Determinants of its effectiveness. International Journal of Advertising, 32(1), 101-119. http://dx.doi.org/10.2501/IJA-32-1-101-119

Dholakia, R., \& Stemthai, B. (1977). Highly credible source: Persuasive facilitator or persuasive liabilities?. Journal of Consumer Research, 3(4), 223-232. http://www.jstor.org/stable/2489608

Elberse, A., \& Verleun, J. (2012). The economic value of celebrity endorsements. Journal of Advertising Research, 52(2), 149-165. http://dx.doi.org/10.2501/JAR-52-2-149-165

Erdem, T., \& Swait, J. (2004). Brand credibility, brand consideration, and choice. Journal of Consumer Research, 31(1), 191-198. https://doi.org/10.1086/383434

Erdogan, B. Z. (1999). Celebrity endorsement: A literature review. Journal of Marketing Management, 15(4), 291-314. http://dx.doi.org/10.1362/026725799784870379

Fornell, C., \& Larcker, D. F. (1981). Structural equation models with unobservable variables and measurement error-algebra and statistics. Journal of Marketing Research, 18(3), 382-388. http://www.jstor.org/stable/3150980

Friedman, H. H., \& Friedman, L. (1979). Endorser effectiveness by product type. Journal of Advertising Research, 19(5), 63-71.

Gehlhar, M., \& Regmi, A. (2005). Factors shaping global food markets. In A. Regmiand \& M. Gehlhar (Eds.), New Directions in Global Food Markets (pp. 5-17). Agriculture Information Bulletin Number 794, United States Department of Agriculture.

Goldsmith, R. E., Lafferty, B. A., \& Newell, S. J. (2000). The impact of corporate credibility and celebrity credibility on consumer reaction to advertisements and brands. Journal of Advertising, 29(3), 43-54. http://www.jstor.org/stable/4189151

Goutam, D. (2013). Influence of brand ambassadors on buying behavior of soft drinks: With reference to Belgaum city. International Journal of Research in Business Management, 1(4), 9-18.

Hair, J., Anderson, R. E., Tatham, R. L., \& Black, W. C. (1998). Multivariate data analysis (5th ed.). New York: Macmillan. 
Hair, J., Black, B., Babin, B., Anderson, R., \& Tatham, R. (2006). Multivariate data analysis: Upper saddle river. NJ: Pearson Prentice Hall.

Hakimi, B. Y., Abedniya, A., \& Zaeim, M. N. (2011). Investigate the impact of celebrity endorsement on brand images. European Journal of Scientific Research, 58(1), 116-132. https://doi.org/10.1108/17473611311325564

Hattie, J. (1985). Methodology review: Assessing unidimensionality of tests and ltems. Applied Psychological Measurement, 9(2), 139-164. https://doi.org/10.1177/014662168500900204

Hovland, C. I., Irving, K. J., \& Harold, H. K. (1953). Communication and persuasion. New Haven: Yale University Press.

Hur, W., Kim, H., \& Woo, J. (2014). How CSR leads to corporate brand equity: Mediating mechanisms of corporate brand credibility and reputation. Journal of Business Ethics, 125(1), 75-86. https://doi.org/10.1007/s10551-013-1910-0

Hussain, S., Mehmood, R. W., \& Khan, F. S. (2012). Impact of celebrity endorsement on brand equity with mediating role of brand trust. International Journal of Research in Commerce and Management, 3(12), 28-32.

Jain, V. (2011). Celebrity endorsement and its impact on sales: A research analysis carried out in India. Global Journal of Management and Business Research, 11(4), 69-84.

Johansson, J., \& Sparredal, J. (2002). Celebrity endorsements: A case study of Axa and the Ludmila Engquist incident (Unpublished bachelor thesis). Lulea University of Technology.

Johnson, J. A. (2005). Ascertaining the validity of individual protocols from web-based personality inventories. Journal of Research in Personality, 39(1), 103-129. https://doi.org/10.1016/j.jrp.2004.09.009

Junco, R., \& Cotton, S. R. (2012). No A 4 U: The relationship between multitasking and academic performance. Computers and Education, 59(2), 505-514. https://doi.org/10.1016/j.compedu.2011.12.023

Kaiser, H. F. (1960). The application of electronic computers to factor analysis. Educational and Psychological Measurement, 20(1), 141-151.

Kamins, M. A. (1989). Celebrity and non-celebrity advertising in a two-sided context. Journal of Advertising Research, 29(3), 34-42.

Kamins, M. A., Brand, M. J., Hoeke, S. A., \& Moe, J. C. (1989). Two-sided versus one-sided celebrity endorsements: The impact on advertising effectiveness and credibility. Journal of Advertising, 18(2), 4-10. http://www.jstor.org/stable/4188716

Kelman, H. C., \& Hovland, C. I. (1953). Reinstatement of the communicator in delayed measurement of opinion change. Journal of Abnormal and Social Psychology, 48(3), 327-335. http://dx.doi.org/10.1037/h0061861

Kemp, E., \& Bui, M. (2011). Healthy brands: Establishing brand credibility, commitment and connection among consumers. Journal of Consumer Marketing, 28(6), 429-437. https://doi.org/10.1108/07363761111165949

Koordeman, R., Anschutz, D. J., Van Baaren, R. B., \& Engels, R. C. M. E. (2010). Exposure to soda commercials affects sugar-sweetened soda consumption in young women: An observational experimental study. Appetite, 54(3), 619-622. https://doi.org/10.1016/j.appet.2010.03.008

Larkina, P., Mesagnoa, C., Berry, J., \& Spittle, M. (2014). Development of a valid and reliable video-based decision-making test for Australian football umpires. Journal of Science and Medicine in Sport, 17(5), 552-555.

Leatherhead Food Research. (2014). Soft drinks microbiology. Retrieved 05 June 2016, from http://www.leatherheadfood.com/soft-drinks-microbiology

Ledesma, R. D., \& Valero-Mora, P. (2007). Determining the number of factors to retain in EFA: An easy-to-use computer program for carrying out Parallel Analysis. Practical Assessment, Research and Evaluation, 12(2), $1-11$

Lee, T. H. (2013). Influence analysis of community resident support for sustainable tourism development. Tourism Management, 34(1), 37-46. https://doi.org/10.1016/j.tourman.2012.03.007

Lord, K. R., \& Putrevu, S. (2009). Informational and transformational responses to celebrity endorsements. Journal of Current Issues and Research in Advertising, 31(1), 1-13. http://dx.doi.org/10.1080/10641734.2009.10505253 
Lumsden, J. (1961). The construction of unidimensional tests. Psychological Bulletin, 58(2), 122-131. http://dx.doi.org/10.1037/h0048679

Maathuis, O., Rodenburg, J., \& Sikkel, D. (2004). Credibility, emotion, or reason?. Corporate Reputation Review, 6(4), 333-345.

MarketWatch. (2006). A-list celebrity endorsements are failing to dazzle consumers. Market Watch: Global Round-Up, 5(9), 29-30.

Martin, C. A. (2005). From high maintenance to high productivity: What managers need to know about Generation $Y$. Industrial and Commercial Training, 37(1), 39-44. https://doi.org/10.1108/00197850510699965

Mathew, T., Casamassimo, P. S., \& Hayes, J. R. (2002). Relationship between sports drinks and dental erosion in 304 university athletes in Columbus, Ohio, USA. Caries Res, 36(4), 281-287. https://doi.org/10.1159/000063927

McCracken, G. (1989). Who is the celebrity endorser? Cultural foundations of the endorsement process. Journal of Consumer Research, 16(3), 310-321. http://www.jstor.org/stable/2489512

McGuire, W. J. (1985). Attitudes and Attitude changes. In G. Linzey and E. Aronson (Eds.), Handbook of Social Psychology (pp. 233-346), New York: Random House.

Mendis, C. (2012). Three icons form Beverage Association of Sri Lanka. Daily Financial Times, Retrieved 05 June 2016, from http://www.ft.lk/2012/08/09/three-icons-form-beverage-association-of-sri-lanka

Money, R. B., Terence, A. S., \& Sakano, T. (2006). Celebrity endorsements in Japan and the United States: Is negative information all that harmful?. Journal of Advertising Research, 46(1), 113-123. https://doi.org/10.2501/S0021849906060120

Muda, M., Musa, R., \& Putit, L. (2012). Breaking through the Clutter in media environment: How do celebrities help?. Procedia-Social and Behavioral Sciences, 42, 374-382. https://doi.org/10.1016/j.sbspro.2012.04.201

Muda, M., Musa, R., Mohamed, R. N., \& Borhan, H. (2014). Celebrity entrepreneur endorsement and advertising effectiveness. Procedia-Social and Behavioral Sciences, 130, 11-20. https://doi.org/10.1016/j.sbspro.2014.04.002

Netemeyer, R. G., Krishnan, B., Pullig, C., Wang, G., Yagci, M., Dean, D., Ricks, J., \& Wirth, F. (2004). Developing and validating measures of facets of customer-based brand equity. Journal of Business Research, 57(2), 209-224. https://doi.org/10.1016/S0148-2963(01)00303-4

Nunnally, J.C. (1978). Psychometric theory, New York: McGraw-Hill.

Ohanian, R. (1990). Construction and validation of a scale to measure celebrity credibility. Journal of Advertising, 19(3), 39-52. http://dx.doi.org/10.1080/00913367.1990.10673191

Ohanian, R. (1991). The impact of celebrity spokesperson's perceived image on consumers' intention to purchase. Journal of Advertising Research, 31(1), 46-52.

Ojha, N. (2013). Role of advertisement in managing the brand equity of carbonated drinks among Generation-Z. International Journal of Applied Services Marketing Perspectives, 2(4), 597-601.

Owen, S. V. (2009). Making sense of published statistics. Perioperative Nursing Clinics, 4(3), 245-258.

Pughazhendi, A., \& Ravindran, D. S. (2012). A study on the influence of using celebrity endorsements on consumer buying behaviour in Tamil Nadu, India. Journal of Research in International Business Management, 2(4), 89-96.

Ratneshwar, S. S., \& Chaiken, S. (1991). Comprehension's role in persuasion: The case of its moderating effect on the persuasive impact of source cues. Journal of Consumer Research, 18(1), 52-62. http://dx.doi.org/10.1086/209240

Rossiter, J. R. (2011). Marketing measurement revolution: The C-OAR-SE method and why it must replace psychometrics. European Journal of Marketing, 45(11-12), 1561-1588. https://doi.org/10.1108/03090561111167298

Seno, D., \& Lukas, B. A. (2007). The equity effect of product endorsement by celebrities: A conceptual framework from a co-branding perspective. European Journal of Marketing, 41(1-2), 121-134. https://doi.org/10.1108/03090560710718148 
Shamim, A., \& Butt, M. M. (2013). A critical model of brand experience consequences. Asia Pacific Journal of Marketing and Logistics, 25(1), 102-117. https://doi.org/10.1108/13555851311290957

Sharma, K., \& Kumar, S. S. (2013). Celebrity endorsement in advertising: Can it lead to brand loyalty in the long run?. International Journal of Marketing, Financial Services and Management Research, 2(3), 73-79.

Silvera, D. H., \& Austad, B. (2004). Factors predicting the effectiveness of celebrity endorsement advertisements. European Journal of Marketing, 38(11-12), 1509-1526. https://doi.org/10.1108/03090560410560218

Singh, B. (2012). Impact of advertisement on the brand preference of aerated drinks. Asia Pacific Journal of Marketing and Management Review, 2(2), 147-160.

Smithers Pira. (2014). Discussion: What is the current state of the carbonated drinks market, Retrieved 05 June 2016, from https://www.smitherspira.com/news/2014/june/the-current-state-of-the-carbonated-drinks-market

Solomon, M. R. (1996). Consumer behavior (3rd ed.). London: Prentice- Hall International.

Spry, A., Pappu, R., \& Cornwell, T. B. (2011). Celebrity endorsement, brand credibility and brand equity. European Journal of Marketing, 45(6), 882-909. https://doi.org/10.1108/03090561111119958

Streiner, D. L. (1994). Figuring out factors: The use and misuse of factor analysis. Canadian Journal of Psychiatry, 39(3), 135-140.

Sweeney, J., \& Swait, J. (2008). The effects of brand credibility on customer loyalty. Journal of Retailing and Consumer Services, 15(3), 179-193. https://doi.org/10.1016/j.jretconser.2007.04.001

Tharanikaran, V., Sritharan, S., \& Thusyanthy, V. (2017). Service quality and customer satisfaction in the electronic banking. International Journal of Business and Management, 12(4), 67-83. https://doi.org/10.5539/ijbm.v12n4p67

Thusyanthy, V. (2016, June). Assessing the levels of health consciousness and customer based brand equity in Sri Lanka. Proceedings of Research Conference on Business Studies, Vavuniya Campus of the University of Jaffna, Sri Lanka, 119-124.

Thusyanthy, V., \& Senthilnathan, S. (2012). Customer satisfaction in terms of physical evidence and employee interaction. IUP Journal of Marketing Management, 11(3), 7-24.

Thusyanthy, V., \& Senthilnathan, S. (2013). Level of job satisfaction and its association with demographic variables. IME Journal, 7(2), 39-45.

Thusyanthy, V., \& Tharanikaran, V. (2015). The relationship variables to celebrity endorsement and brand equity: A comprehensive review. International Journal of Business and Management, 10(11), 212-221. http://dx.doi.org/10.5539/ijbm.v10n11p212

United Nations Industrial Development Organization. (2014). Greening food and beverage value chains: The case of the soft drinks industry: a report for the UNIDO green industry initiative. Retrieved 05 June 2016, from

http://www.greenindustryplatform.org/wp-content/uploads/2014/09/Greening-Value-Chains_Softdrinks-Ind ustry_2014.pdf

VinayagaMoorthy, A., \& Madevan, P. (2014). A study on influence of advertisement in consumer brand preference: Special reference to soft drinks market in Hosur town. International Journal of Business and Administration Research Review, 2(3), 69-76.

Vlachvei, A., \& Oustapassidis, K. (1998). Advertising, concentration and profitability in Greek food manufacturing industries. Agricultural $\quad$ Economics, $191-198$. https://doi.org/10.1016/S0169-5150(98)80007-8

Wang, X., \& Yang, Z. (2010). The effect of brand credibility on consumers' brand purchase intention in emerging economies: The moderating role of brand awareness and brand image. Journal of Global Marketing, 23(3), 177-188. http://dx.doi.org/10.1080/08911762.2010.487419

Wei, P., \& Lu, H. (2013). An examination of the celebrity endorsements and online customer reviews influence female consumers' shopping behavior. Computers in Human Behavior, 29(1), 193-201. https://doi.org/10.1016/j.chb.2012.08.005

Yoo, B., \& Donthu, N. (2001). Developing and validating a multidimensional consumer-based brand equity scale. Journal of Business Research, 52(1), 1-14. https://doi.org/10.1016/S0148-2963(99)00098-3 
Yoshida, M., \& Gordon, B. (2012). Who is more influenced by customer equity drivers? A moderator analysis in a professional soccer context. Sport Management Review, 15(4), 389-403. https://doi.org/10.1016/j.smr.2012.03.001

Zaichkowsky, J. L. (1985). Measuring the involvement construct. Journal of Consumer Research, 12(3), $341-352$. http://www.jstor.org/stable/254378

Zdravkovic, S., Magnusson, P., \& Stanley, S. M. (2010). Dimensions of fit between a brand and a social cause and their influence on attitudes. International Journal of Research in Marketing, 27(2), 151-160. https://doi.org/10.1016/j.ijresmar.2010.01.005

\section{Copyrights}

Copyright for this article is retained by the author(s), with first publication rights granted to the journal.

This is an open-access article distributed under the terms and conditions of the Creative Commons Attribution license (http://creativecommons.org/licenses/by/4.0/). 